\title{
Digital Technologies in Management of Logistic Systems on the Transport Service Market
}

\author{
Kalyakina I.M.* Sakharova O.N. Dmitrieva I.A.
}

\author{
Don State Technical University, Rostov-on-don, Russia \\ *Corresponding author. Email: inessakalyakina@yandex.ru
}

\begin{abstract}
The paper deals with the possibilities of using digital technologies in logistic system management, and the possibility of improving logistic flows on the transport service market. The transport sector is of the fundamental importance for our global economy and represents one of the pillars of international and interregional trade. Transport component, on the one part, performs the supporting function, providing cargo and passenger movement in various directions with the set level of service; on the other part, transport development is determining for stimulation and concentration of industrial and trade enterprises. The possibility of prospective transport and logistic service, combining several means of transport with the considerable carrying capacity is determining at the choice of location of warehouse logistic infrastructure, branches of large network trade companies and industrial enterprises.
\end{abstract}

Keywords: logistics, transportation, economy, tariff, logistic system improvement, social and economic

systems, management process digitalization, digital technologies in management

\section{INTRODUCTION}

Transport logistics allows solving issues of material flow management on transport sites, in particular, it enables the organizations to carry out their activities in the most rational way. The transport infrastructure in Russia is the single transport network of railway, motor, water, air, wireless communications. There are distinguished numerous transport and forwarding companies offering cargo transportation and storage services.

This creates the need for building an efficient logistic strategy and implementing contemporary management methods of the motor transport enterprise.

Theoretical grounds of creating the logistic strategy in the company are contained in papers of Russian investigators: S. Taran, S.V. Sarkisov, and many others. Moreover, foreign scientists also deal with this issue: M. Porter, I. Ansoff, A. Chandler, et al.

So far, determination of the logistic system notion has a very versatile nature. The main objective of the logistic system is the delivery of products and items to the specified place in the specified stock and number. As a rule, "logistic chain, or supply chain" is more often used by foreign specialists. If we consider the logistic system in terms of system approach to business planning, this definition can be formulated as a rather stable aggregate of links, structural and functional company departments, suppliers, logistic mediators and, of course, consumers, united and interconnected with one level of business organization strategy.

The logistic system can be composed of real elements (links) differing by:

1) form of incorporation or form of business entity;
2) nature and goals of functioning;

3) production capacity, production concentration level,

4) dependence of the activity results on a large number of external factors and adjacent links, etc.

The logistic system links are divided into three types: absorbing, generating and transforming material and accompanying finance and information flows. There exist logistic system links that combine all types of links. Such mixed links are combined in various combinations. Material flows in logistic system links can change their content, be fragmented, change parameters, intensity, can assemble and divaricate, etc. [7].

\section{METHODS}

When considering the logistic channels at the macro level, they are connections between the macrologistic subsystems [6]. At this, the construction of logistic chains and separating links can also occur on the micro-level. Figure 1 shows the example of the logistic chain of supplies where the examples of links are enterprises, independent on each other, the interaction of which is carried out on a partnership basis.

The enterprise operation efficiency greatly depends on the chain, the link of which it is. Reaching the efficient interorganization coordination in the supply chain allows discussing the increase of operational results of the supply chain and its separate links 1 . 


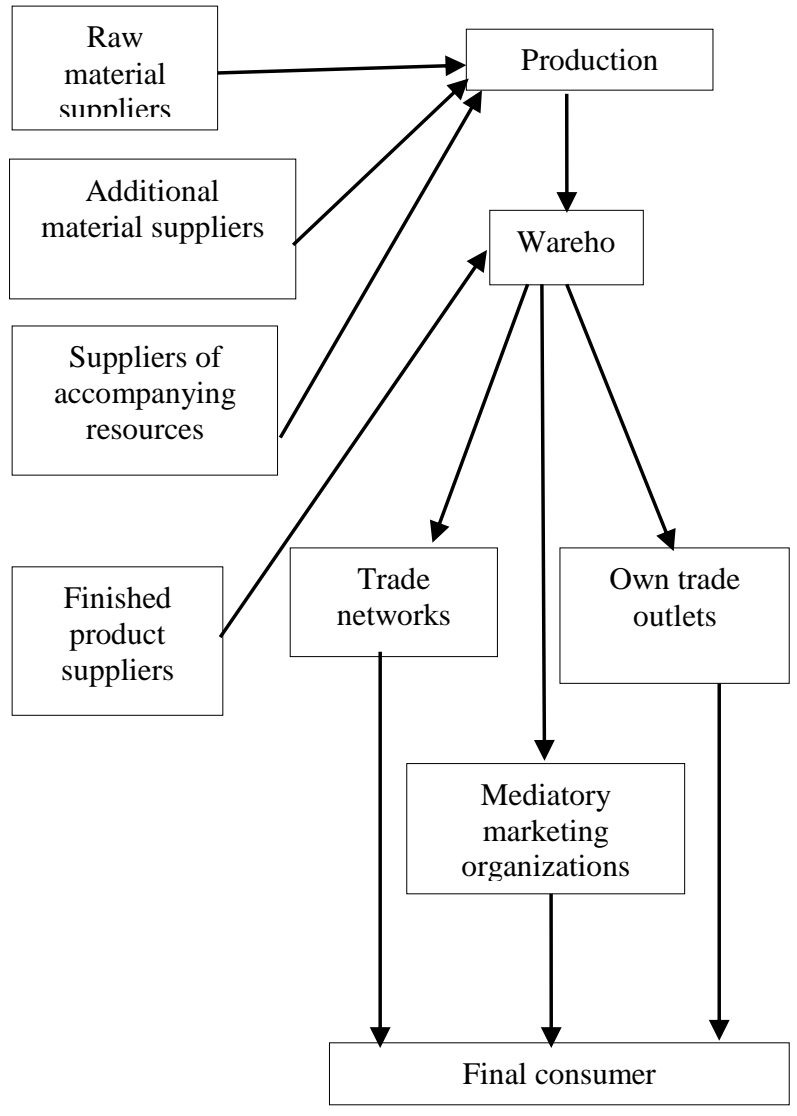

Figure 1 Logistic chain example

At the supply chain design, the certain "conflict of interests" of the link companies is inevitable. It should be understood that any comercial company sets itself a goal of income extracting from its activity, and at this, the strategy of possible cessions to the partner conforms to this, not always to the maximal extent, at the first sight.

However, in the presence of a modern approach to competition between the supply chains, a rather fast finding of the efficient interaction mechanisms allows improving the parameters of material flow passing through the logistic chain links, thus increasing the competitive ability of a product offered by this chain for the final consumer. Possibilities of increasing the technical characteristics of the chain links due to the release of financial resources for investig into the main type of activity and cessation (decrease) of expenses under nonkey directions should also be mentioned. Finished products are also not warehoused in production but is transferred to the dealer centers that ordered the item. Forming the production plan based on the existing orders of official trade representatives excludes the possibility of stock accumulation and declaration of current assets movement. The logistic approach at the organization of interaction in the supply chain allows, using the chain link interaction, to obtain more expected indicators of the material and the accompanying flows on the output.

Modern logistic concepts provide for the formation of relations under the main types of companies' activity that are principally different from the conventional approach. Introduction of progressive methods into the functionality of transport enterprises and the formation of the efficient logistic strategy are so far the necessary conditions of receiving balance progress and considerable competitive advantages in the field of transport and logistic services. For the last ten years, the economic world changed greatly: First, the value importance of goods and services changed because now the demand is higher for the product which is the most adapted to the specific user's certain needs and is delivered in the most convenient way at the required time; second, the market is controlled by consumers who thoroughly understand their conditions and all the resulting privileges and possibilities.

Third, new methods of technology and production appeared, and the importance of information technologies increased. The latter turned from the base for many other technologies into the document of bringing information to buyers.

Despite the aforementioned management peculiarities, most of the transport companies continue to be guided by obsolete managerial principles and ideas in their activity.

Based on this, the objective need arises to rethink over the ways of building and organization, business processes circulating in the enterprise, and the use of an absolutely different approach allowing the full implementation of new technologies and programs, together with human resources.

The transport sector is of the fundamental importance for our global economy and represents one of the pillars of international and interregional trade. Nevertheless, it takes into account the considerable negative impacts, such as emissions, noise, and traffic jams. This requires the modal shift to structuring $\mathrm{h}$ more efficient systematic network that allows fully use the available potentials in the entire transport sector. Recently, the efficient combination of several means of transport, such as railway, sea and cargo transport, within one system, has been in the center of attention. It should be achieved without any processing of cargo itself at the regime change. This method reduces cargo processing, increases safety, decreases damage and allows transporting cargo at a higher speed.

In this relation, the European Union determined the intermodality as the "transport system characteristics", in which, at least, two different means are used in an integrated manner for carrying out the door-to-door transportation sequence." The resulting global approach allows using the existing transport facilities in a more rational way".

Nevertheless, the "door-to-door" supply chain has a potential for a more considerable quitting the intermodal approach due to new innovations in the sphere of ICT and data system integration. By means of digitalization in this area, it would be possible to establish the real "synergy" between the participants of the supply and logistic chain. As a result, the Synchromodality concept was created 
beyond the other concepts of Unimodality, Multimodality, and Intermodality for the optimal use of the capacity available.

As a concept, the synchromodality tries to provide more importance for railway and internal water transport by offering an efficient and smooth switch between these two means of transport and motor transport. It considers cargo transportation in terms of the entire modal network, in order to select regimes based on the optimization principle. The synchromodality is determined as the "evolution of concepts of inter- and comodal transportation, when the interested parties of the transport chain actively interact in terms of common network with the process of flexible planning of transport processes and having a possibility to switch in real time between the means of transport adapted to the available ones".

Resources. The shipper determines only the main requirements to transport, such as cost, duration, and stability aspects, in advance. Therefore, transport processes can be optimized, and the existing resources can be sustainably and completely used." In 2012, Paul Ham also called this the "optimal use of all means of transport and the available carrying capacity at any time as the integrated transport solution." Consequently, the synchromodal transport is the well-considered use of the entire capacity available.

The concept is based on two elements of transport networks and booking without the regime. This allows a transport company collecting orders from clients and optimizing the flows. Efficient cooperation will allow carrying out shiftment by resource-saving and flexible way. Moreover, the use of integrated digital data systems allows reasonably selecting the most efficient way of goods. It means determining priorities and balancing time, expenses, services and even special functions, such as carbon trace.

Despite the fact that the main attention is paid to a lowcarbon economy, the synchromodality is unknown in most of the regions of Europe on the EU level, except for Belgium, the Netherlands, and Luxembourg. In terms of environment, while the most attention is paid to decarbonisation, the system synergic approach in the field of logistics, internal districts and transport can considerably increase the environment indicators of cargo transportation. For this purpose, we will determine the key aspects of the synchromodal transport.

\section{DRIVERS AND ISSUES}

There exist four drivers able to accelerate the "door-todoor" delivery chain to connective networks of the synchromodal structure:

- High and unstable fuel price rising the need for economic transport solutions;

- Huge growth of overloaded road infrastructure;

- Raising environmental awareness and society awareness about the traffic side effects for local communities;
- Strict standards of environmental management on the interregional and international level, such as Paris Agreement and Agreement of the International Maritime Organization (IMO) Members for at least by $50 \%$ by 2050 when compared to 2008 .

First, interaction and cooperation with the core of the concept of trust and relations with customers. Creating such a network is based on mutual respect and trust as the crucial prerequisite of the synchromodal processes. Due to the fact that numerous organizations do not wish to cooperate with competitors, a new way of thinking is required for the creation of the synchromodal network which is focused on trust and advantages of cooperation instead of competition.

The second limitation is the planning complexity. Planning and simulation of transport routes are vital for creating an efficient synchromodal transport network. Such elements as new preferences of the customers, movement routes, and available resources of logistic units, should be assessed and studied prior to the planning. Monitoring and forecasting are key factors for transport indicators optimization. Respectively, the network of cargo transportation should be created on the basis of demand and forecasting mapping tools.

The third limitation is the possibility to connect the existing IT systems and data exchange platforms. A quality data exchange platform is a key to mutual data exchange from different interested parties, such as shipping company, forwarding agent, and port terminal; The third limitation is the possibility to connect the existing IT systems and data exchange platforms. A quality data exchange platform is a key to mutual data exchange from different interested parties.

The third limitation is the possibility to connect the existing IT systems and data exchange platforms. A quality data exchange platform is a key to mutual data exchange from different interested parties

Besides the limitations mentioned, there are four groups of barriers for the synchromodal transport network use:

1. Operational issues, such as train noninteraction, terminal working hours, use of railway infrastructure both for passenger and cargo transportation.

2. Issues of organizational operation, such as coordination between participants and establishing relations between various partners.

3. In some cases, economic challenges due to the higher overload cost

4. The absence of prospective business models using new technologies requiring higher integration and information exchange for creating synchronized services.

Nevertheless, synchromodal advantages have excessive weight, and motivate participants, in particular, multimodal transport companies and logistic centers, to transfer to synchromodality in a modal way. According to the study carried out by Joana Cuna in the University of Lisboa, benefits from the use of synchromodal structure in the transport logistics are as follows:

- Flexibility increase in transport selection

- Increase in the use of railway and internal water ways 


\section{DISCUSSION}

- Possible decrease of carbon trace

The goal of synchronous modality is replacing the longterm transition from unimodal transport to smart, flexible and sustainable network transport. In terms of this structure, several means of transport are used from intermodality. while the efficiency element was borrowed from the co-modality concept. Therefore, existing transport resources are used in an optimized and sustainable approach. The implementation of efficient synchronous modality depends on various requirements. Due to the fact that the concept is mostly based on synergy and systematic coordination between the interested parties in the transport chain. It means that close cooperation is the main task as the result of the efficient and flexible use of resources.

The most important fields of transport logistics are: the process of planning and implementing the cargo delivery, control over transport and other operations, appearing on the cargo route, and information provision to cargo owners and other interested subjects. The definition of the delivery rational route, type and kind of means of transport, become especially important, and it greatly affects the decrease of transportation costs.

Table 1 Comparative analysis of services of Russian transport companies

\begin{tabular}{|c|c|c|c|c|c|}
\hline \multirow[t]{2}{*}{ Services of transport companies } & \multicolumn{5}{|c|}{ Transport company name } \\
\hline & ZhelDorEkspeditsiya & Delovye Linii & Energiya & DPD & DHL \\
\hline Auto transportation within Russia & + & + & + & + & + \\
\hline Transportation by truck & - & + & - & + & - \\
\hline Air transportation & - & + & + & - & + \\
\hline Sea transportation & - & - & - & - & + \\
\hline Railway transportation & + & - & + & + & + \\
\hline Container transportation & + & + & - & - & + \\
\hline Joint cargo & + & + & + & + & + \\
\hline Document delivery & - & + & + & - & + \\
\hline Hazardous cargo & - & - & - & + & - \\
\hline Dedicated transport & + & + & + & - & + \\
\hline Oversize cargo & + & - & + & + & + \\
\hline Delivery for online stores & + & - & + & + & + \\
\hline Delivery for supermarkets & - & + & - & + & + \\
\hline Express delivery & + & + & - & - & + \\
\hline Custody & + & + & - & + & + \\
\hline Customs clearance & - & - & - & - & + \\
\hline Refrigerator transportation & + & - & - & - & - \\
\hline Geography & Russia, Kazakhstan & $\begin{array}{c}\text { Russia, } \\
\text { Kazakhstan, } \\
\text { Armenia, } \\
\text { Belarus, } \\
\text { Kirgizia }\end{array}$ & $\begin{array}{c}\text { Russia, } \\
\text { Kazakhstan, } \\
\text { Armenia, } \\
\text { Belarus, } \\
\text { Kirgizia, } \\
\text { China, the } \\
\text { Euroean } \\
\text { Union, PDR, } \\
\text { PLR }\end{array}$ & $\begin{array}{c}\text { Russia, } \\
\text { Mir }\end{array}$ & Russia, Mir \\
\hline
\end{tabular}

According to the data submitted, motor transportation is carried out by all analyzed companies, and the selection of
Often, transportation by specialized companies is the most optimal solution. This option is the most efficient because all participants of the transport and logistic process will interact with each other, with all their actions coordinated and, consequently, economically efficient. At such transportation organization form, transport flow management is uniform, allowing accurate planning of goods delivery in the specific time with minimal costs.

An important task for organizations is selecting the type and kind of the means of transport for cargo transportation. The cargo properties have the crucial role in the selection. As a rule, criteria when selecting the means of transport are: transportation speed, load capacity and capacity, cargo preservation, and transportation proce.

The following companies were selected as objects of analysis of Russian transport companies: ZhelDorEkspeditsiya, Delovye Linii, Energiya, DPD, DHL. The services of these transport companies, allowing to assess their competitive advantages for consumers, are given in Table 1. one of them, in this case, depends on the geographical factor. However, truck transportation is carried out only by 
two companies, the most achievement-oriented of which in terms of geography is "DPD".

Railway transportation is carried out by four of five analyzed companies. Compared to other transportation types, railway cargo transportation has the line of advantages: the absence of dependence on weather conditions, strict traffic schedule, absence of seasonality that affects price formation. The most achievementoriented in terms of transport of this kind in Russia and Kazakhstan is "ZhelDorEkspeditsiya" because it has the exclusive competitive advantage: the possibility of refrigeration transportation. Moreover, this company provides for custody, container transportation and transportation of

assorted cargo, that is the most economically beneficial for most of the organizations because assorted cargo transportations allow reducing the transport cost considerably while being carried out under the set schedule and accompanied by $24 / 7$ dispatch monitoring. In addition, railway transportation is provided by the following companies: "Energiya", "DPD" and "DHL", but container transportation is carried out only by "DHL". Only "DPD" delivers hazardous cargo which is its competitive advantage in this field.

There is a line of the other competitive advantages of the companies analyzed concerning the services provided but, in terms of economic analysis, the most important factor will be the transportation cost. For this, the specific example will be given of cargo transportation from Taganrog city to Moscow city, with the price calculation data given in Table 2.

Table 2 Cost of company cargo transportation

\begin{tabular}{|c|c|c|}
\hline \multirow{2}{*}{ Cargo characteristic } & \multicolumn{2}{|c|}{ Transportation type } \\
\cline { 2 - 3 } & Joint cargo & Gazel \\
\hline Weight, $\mathrm{kg}$ & \multicolumn{2}{|c|}{100} \\
\hline Volume, $\mathrm{m}^{3}$ & \multicolumn{2}{|c|}{0,001} \\
\hline Delovye Linii & \multicolumn{2}{|c|}{ Term of delivery } \\
\cline { 2 - 3 } Total delivery cost, RUB & - days & - days \\
\cline { 2 - 3 } & 1112,5 & 35000 \\
\hline ZhelDorEkspeditsiya & $3-5$ days & - \\
Total delivery cost, RUB & 745 & - \\
\hline Energiya & $4-8$ days & - \\
Total delivery cost, RUB & 1190 & - \\
\hline DPD & \multicolumn{2}{|c|}{$4-3$ days } \\
Total delivery cost, RUB & \multicolumn{2}{|c}{2977,6} \\
Money-saving tariff: & \multicolumn{2}{|c}{993,12} \\
Optimal tariff: & \multicolumn{2}{|c|}{} \\
\hline
\end{tabular}

There is no possibility for cargo value online calculation in DHL.

Therefore, according to the data received, a conclusion can be made that the least expensive and the fastest will be the transportation of assorted cargo by "ZhelDorEkspeditsiya". But, when it is required to ship not the assorted cargo, "Delovye Linii" provides this service, and cargo transportation in it will exceed the assorted cargo transportation value several tens of times. In addition, "Delovye Linii" has a competitive advantage according to the rule of geographical distribution, compared to "ZhelDorEkspeditsiya".

It should be mentioned that each of the companies analyzed provides the entire line of additional services influencing their competitive ability. For example, the important service is cargo insurance which is provided by all companies being analyzed.

The selection of a certain company depends on the cargo specifics, time limits, transportation cost, and the geographical factor.

\section{CONCLUSION}

The use of logistics for the service accompanying the process of passenger transportation by motor transport conditions the need for revealing the life cycle of logistic services, depending on many factors, the systematization of which allows providing the process of service and managerial events improvement.

An important decision activating the logistic service of passenger motor transportation in the region is developing the criteria of assessing the general efficiency of motor transport enterprises, with the use if an integral indicator consisting of internal and external components of the motor transport enterprise. With the purpose to increase the assessment performance, it is required to determine basic indicators providing logistic service efficiency, quality, reliability, and safety.

For a radical impact on the logistic service quality management in performing passenger moto transportation, it is required to use the dimensional chain methodology, the Six Sigma methodology, PMEA analysis, improving the passenger motor transport operation cycles, its safety, and efficiency.

With the purpose to increase the logistic service performance, it is recommended to use the quality management principles, methods, and instruments allowing to efficiently solve issues related to passenger motor transportation. With this purpose, in order to provide the system of interactions between the departments involved in management, control, organization of passenger transportation by motor transport, the passenger transportation logistic service management department should be created within the Ministry of Highways, Transport and Communication of Rostov Region.

In conditions of financial crisi and economic instability development, the cost decrease mode and the service quality management efficiency increase form the basis for any business functioning. Economic processes occurring in organizations dealing with logistic services require considerable spending of material, labor, and information resources. Enterprises providing transport services to people face issues raised by the transformation economy specifics. The fuel price increase, obsolescent carrying equipment, low quality of services provided, lack of 
upravleniye. 2013. Rezhim dostupa:

financial instruments, issues of transportation safety provision, the use of obsolete management methods make the incomplete list of problems in the Russian transport sector. The growing mobility of the population and annual growth of the passenger transportation market requires the respective development in the field of logistical service provision. Legislation basis, norms and standards regulating the order of organization and provision of transportation services to the population are obsolete by now. The present economic situation on the motor transport service market proves the need for search of new economy reserves, carrying out work for reconsideration of the line of processes from the positions of expenses decrease and increase of the provided services quality. Improving the management of logistic service quality with the use of the quality management system principles requires the respective scientific knowledge and practical aspects of the activity of enterprises involved in the field of service.

\section{REFERENCES}

[1] Problemy razvitiya avtomobil'nogo transporta v Rossii [Elektronnyy resurs]. URL:https://1000statei.ru/articles/problemy-razvitiyaavtomobilnogo-transporta-v-rossii.html Data obrashcheniya: 08.12.19

[2] A.A. Borisova, I.M. Kalyakina, N.Y. Bondarenko, Development of methods of the solution of management problems in social and economic systems, International Business Management. 2014. T. 8. № 6. P. 348-352

[3] I.M. Kalyakina, N.Y. Bondarenko, Methods of adoption of administrative decisions of investment character in the socio-economic systems, V sbornike: Aktual'nyye napravleniya fundamental'nykh i prikladnykh issledovaniy Materialy $\mathrm{X}$ mezhdunarodnoy nauchno-prakticheskoy konferentsii: v 2-kh tomakh. Nauchno-izdatel'skiy tsentr «Akademicheskiy». 2016. P. 140-142.

[4] L. Thompson, Railway Gazette International, 2006. № 1. P. 27-29. URL: http://www.css-rzd.ru/zdm/200602/06006.htm.

[5] G. A. Kovalev, Logisticheskaya deyatel'nost' na zheleznodorozhnom transporte: sostoyaniye i perspektivy, Global'nyy mir: mnogopolyarnost', antikrizisnyye imperativy, instituty: materialy V Mezhdunar. nauchn.-prakt. konf. Rostov n/D, 2014.

[6] A. A. Kizim, Faktory rosta i ugrozy razvitiya sovremennoy transportno-logisticheskoy infrastruktury rossiyskikh territoriy, Nauka i obrazovaniye: khozyaystvo i ekonomika; predprinimatel'stvo; pravo i http://www.journal-

nio.com/index.php?option=com_content $\&$ view=article $\& \mathrm{id}=2053 \&$ Itemid $=125$

[7] Connecting to compete 2012: trade logistics in the global economy - the logistics performance index and its indicators [Electronic resource]. URL: http://documents.worldbank.org/curated/en/2012/01/20 138311/connecting-compete2012-trade-logisticsglobal-economy-logistics-performance-indexindicators.

[8] Federal Ministry of Transport, Building and Urban Development: official site [Electronic resource]. URL: http://www.bmvbs.de

[9] Grant Robert M. Contemporary Strategy Analysis, 2012.537 c.

[10] M. Porter, G. Bond, Innovative Capacity and Prosperity: the Next Competitiveness Challenge in the Global Competitiveness Report. NY, 2011. 